\title{
Metode Jolly Phonics sebagai Metode Membaca Permulaan Siswa Kelas I Sekolah Dasar
}

\author{
Suci Anggraeni ${ }^{1}$, Suyono ${ }^{2}$, Dedi Kuswandi ${ }^{3}$ \\ ${ }^{1}$ Pendidikan Dasar-Universitas Negeri Malang \\ ${ }^{2}$ Bahasa Indonesia-Universitas Negeri Malang \\ ${ }^{3}$ Teknologi Pendidikan-Universitas Negeri Malang
}

\begin{tabular}{l}
\hline \hline INFO ARTIKEL \\
\hline Riwayat Artikel: \\
Diterima: $30-11-2018$ \\
Disetujui: $23-01-2019$ \\
\hline
\end{tabular}

\section{Kata kunci:}

read the beginning;

reading method;

jolly phonics;

membaca permulaan;

metode membaca;

jolly phonics

\begin{abstract}
ABSTRAK
Abstract: The purpose of this study was to determine the effectiveness of the jolly phonics method as a method of reading the beginning readers. The research design uses descriptive qualitative data collection techniques of interviews, observation, documentation studies and literature studies. The findings show that the jolly phonics method is able to overcome reading difficulties with students' learning styles that tend to use the basic language skills and phonics approach through the stages of reading (1) learning the letter sound, (2) learning the letter formation, (3) blending, and (4) identifying the sound in words.
\end{abstract}

\begin{abstract}
Abstrak: Tujuan penelitian ini yaitu untuk mengetahui efektivitas metode membaca Jolly Phonics sebagai metode membaca permulaan siswa kelas I SD. Desain penelitian menggunakan deskriptif kualitatif dengan teknik pengumpulan data wawancara, observasi, studi dokumentasi, dan studi literatur. Temuan menunjukkan bahwa metode Jolly Phonics mampu mengatasi kesulitan membaca dengan gaya belajar siswa yang cenderung menggunakan pendekatan bahasa basic skill and phonics melalui tahapan membaca (1) bunyi huruf, (2) menulis bentuk huruf, (3) memadukan, dan (4) bunyi terhadap bentuk huruf.
\end{abstract}

\author{
Alamat Korespondensi: \\ Suci Anggraeni \\ Pendidikan Dasar \\ Universitas Negeri Malang \\ Jalan Semarang 5 Malang \\ E-mail: suci.anggraeni55@gmail.com
}

Latihan membaca harus dimulai dan dilatih sejak dini. Membaca permulaan memiliki aspek-aspek yang harus dikuasai oleh siswa. Aspek membaca permulaan meliputi pengenalan bentuk huruf, pengenalan unsur-unsur linguistik (fonem/grafem, kata, frase, pola klause, kalimat, dan lain-lain), pengenalan hubungan/korespondensi pola ejaan dan bunyi, kecepatan membaca bertaraf lambat. Tujuan membaca permulaan yang menjadi fokus dalam penelitian ini yaitu untuk melatih dan memperbaiki kemampuan membaca permulaan siswa kelas I SD sehingga mereka nantinya dapat mengenali simbol bahasa (huruf A-Z), melafalkan bunyi dari simbol-simbol huruf A-Z, mengenali huruf, membaca suku kata, kata, sampai kalimat. Tujuan membaca ini dapat membuat siswa memahami makna dari rangkaian simbol bahasa. Pemahaman rangkaian simbol bahasa menggunakan kata atau kalimat sederhana. Tujuan membaca permulaan yang menjadi fokus dalam penelitian ini yaitu untuk melatih dan memperbaiki kemampuan membaca permulaan siswa kelas I SD sehingga mereka nantinya dapat mengenali simbol bahasa (huruf A-Z), melafalkan bunyi dari simbol-simbol huruf A-Z, mengenali huruf, membaca suku kata, kata, sampai kalimat. Tujuan membaca ini dapat membuat siswa memahami makna dari rangkaian simbol bahasa. Pemahaman rangkaian simbol bahasa menggunakan kata atau kalimat sederhana.

Pendekatan bahasa yang digunakan untuk masa kanak-kanak menengah dan akhir menurut (Santrock, 2011) yaitu pendekatan bahasa secara menyeluruh (whole language approach) dan pendekatan keahlian dasar dan fonik (basic skills and phonics). Pendekatan bahasa secara menyeluruh menekankan cara belajar membaca yang bersifat pararel dimana materi-materi yang diberikan secara utuh dan bermakna dengan cara memberikan cerita utuh atau puisi-puisi sehingga mereka belajar dapat memahami fungsi komunikatif berbahasa. Pendekatan keahlian dasar menekankan cara belajar membaca dengan mengajarkan fonik dan aturan-aturan dasarnya dalam menerjemahkan simbol-simbol dalam bentuk bunyi dan melibatkan materi-materi yang disederhanakan. Pendekatan keahlian dasar ini umumnya anak memperoleh suatu materi bacaan yang abstrak dan rumit (contohnya buku teks, puisi, dan buku bacaan ilmiah) mereka peroleh setelah mereka memahami aturan-aturan penyampaian pesan yang melibatkan fonem-fonem lisan dengan huruf-huruf abjad yang mewakili suatu tulisan. 
Pendekatan multisensori yakni pembelajaran melalui aktivitas visual, auditori, kinestetik, dan taktil yang digunakan dalam metode Jolly Phonics sehingga dapat mempermudah siswa dalam mengenali huruf karena siswa belajar melalui lebih dari satu indra siswa secara bersamaan. Pemenuhan kebutuhan gaya belajar siswa beraneka ragam sehingga informasi dapat masuk dan terserap haruslah menggunakan metode yang memungkinkan indra bekerja secara bersamaan supaya penerimaan informasi masuk dan diterima oleh otak (modalitas). Multisensori yang digunakan dalam metode Jolly Phonics menekankan pada aktivitas mengingat, mengenali, dan mengidentifikasi simbol huruf beserta bunyinya melalui visual, auditori, kinestetik, dan taktil yang diterapkan secara bersamaan. Pendekatan multisensori terhadap kemampuan membaca permulaan siswa kelas I SD telah dibuktikan oleh (Dewi, 2015) bahwa pengaruh pendekatan multisensori terhadap kemampuan membawa permulaan siswa pada kelas awal di SD diperoleh informasi bahwa skor terendah pada saat pretest, yaitu 44,4\% dan skor tertinggi yaitu $75,90 \%$, sedangkan perolehan pada saat posttest skor terendah yaitu 70,4\% dan skor tertinggi 77,80\%. Oleh karena itu, dapat dimaknai bahwa kemampuan membaca permulaan mengalami peningkatan melalui pendekatan multisensori.

Hasil analisis siswa kelas I SDN Madyopuro 2 Malang bahwa 10 siswa tersebut memiliki cara belajar yang berbeda dengan siswa lain pada saat belajar membaca. Siswa-siswa tersebut belajar mengenal huruf dengan mendengarkan bunyi-bunyi dan melalui kegiatan menulis. Siswa lebih mudah belajar memalui tahap pengenalan huruf-huruf. Hasil studi pustaka menunjukkan siswa yang memiliki karakteristik membaca melalui mendengarkan bunyi dan mengenal huruf cocok menggunakan metode Jolly Phonics (pendekatan bahasa basic skill and phonics).

Berdasarkan analisis siswa menunjukkan bahwa metode membaca yang sesuai dengan cara siswa belajar membaca yaitu melalui pendekatan keahlian dasar dan fonik. Metode yang sesuai dengan pendekatan dasar dan fonik yaitu metode Jolly Phonics. Metode Jolly Phonics adalah metode membaca yang digunakan untuk mengembangkan kemampuan membaca permulaan siswa di kelas awal melalui sintesa bunyi yang menekankan pada pembelajaran bunyi huruf dan menekankan pendekatan multisensori melalui aktivitas atau kegiatan yang menyenangkan bagi siswa (Llyond, 2007). Strategi yang paling efektif untuk meningkatkan keterampilan membaca dan membaca keaksaraan anak-anak adalah melalui Jolly Phonics (Ariati, Padmadewi, \& Suarnajaya, 2018).

Keunggulan metode Jolly Phonics terdapat pada penekanan mutisensorinya. Pendekatan multisensori yang digunakan dalam metode Jolly Phonics memiliki chiri khas dalam mengenalkan setiap bunyi huruf melalui gerakan atau aktivitas yang mudah diingat, cara belajar aktif yang memungkinkan siswa berpartisipasi dan berksplorasi (Ruhaena, 2008). Jolly Phonics efektif untuk mengajarkan korespondensi grafem dan fonem melalui multi-indera sehingga dapat membantu peserta untuk mengingat bunyi huruf dengan mudah (Faustina, 2008). Analisis kebutuhan menunjukkan bahwa metode membaca yang dipilih untuk merancang multimedia interaktif yaitu metode Jolly Phonics dikarenakan cara belajar siswa kelas I SD lebih mudah dan memahami metode tersebut.

Metode Jolly Phonics sangat menyenangkan dan disukai oleh para siswa dan cara membaca pada metode ini lebih unggul dibandingkan dengan metode konvensional. Hal ini diperkuat oleh pendapat (Nasrawi \& Al-Jamal, 2017) bahwa Jolly Phonics merupakan metode membaca yang menyenangkan bagi siswa dan pra-tes membaca kelompok eksperimental yang terdiri dari 29 murid menunjukkan efek positif. Metode Jolly Phonics berhasil juga berhasil meningkatkan kemampuan membaca siswa. Hal ini dibuktikan oleh penelitian (Sudiarta, 2017) bahwa anak kelompok B yang belajar menggunakan metode Jolly Phonics dengan yang belajar menggunakan konvensional $(\mathrm{F}=4,871$ dengan $\mathrm{p}<0,05)$ artinya Jolly Phonics memberikan pengaruh terhadap kemampuan membaca permulaan siswa.

\section{METODE}

Penelitian yang digunakan yaitu eksperimen dengan rancangan pretest-postest one group sample design. Metode Jolly Phonics merupakan variabel bebas dan membaca permulaan merupakan variabel terikat. Subjek penelitian melibatkan guru dan siswa kelas I SDN Madyopuro 2 Malang. Uji yang dilakukan selanjutnya yaitu menggunakan Pre-Experimental Design Tipe One Group Pretest Postest pada kelompok tunggal. Perolehan skor membaca permulaan siswa baik pre-test maupun post-test akan dihitung selisih nilai dan membandingkan rata-rata dua variabel untuk satu grup sampel tunggal. Hasil perhitungan menggunakan uji-t sampel berpasangan terhadap hasil evaluasi pengetahuan dan kinerja atau performa siswa. Teknik ini digunakan karena subjek yang sama mengalami pengukuran yaitu sebelum dan sesudah diberikan intervensi.

\section{HASIL DAN PEMBAHASAN}

Hasil perhitungan menunjukkan hasil perolehan t hitung yaitu 2,422 dan t tabel yaitu 1,812. Berdasarkan perhitungan tersebut menunjukkan $\mathrm{t}$ hitung $>\mathrm{t}$ tabel yang artinya terdapat perbedaan antara kemampuan membaca atau performa siswa dalam membaca sebelum menggunakan metode membaca Jolly Phonics dan sesudah menggunakan metode Jolly Phonics. Kemampuan membaca siswa kelas I SD mengalami perbedaan, yaitu (1) siswa yang kesulitan mengenal abjad menjadi mengenal abjad bahkan secara acak, (2) siswa yang kesulitan membedakan huruf mirip menjadi mampu membedakan huruf mirip, (3) siswa yang kesulitan mengeja menjadi perlahan mampu membaca meskipun masih terbata-bata, dan (4) siswa belum lancar (terdapat jeda) membaca menjadi lancar membaca meskipun sesekali terdapat jeda dalam membaca. Selain kemampuan 
membaca permulaan, peneliti juga mengukur pengetahuan atau hasil belajar siswa. Hasil perhitungan menunjukkan hasil perolehan $\mathrm{t}$ hitung yaitu 2,663 dan $\mathrm{t}$ tabel yaitu 1,812. Berdasarkan perhitungan tersebut menunjukkan $\mathrm{t}$ hitung $>\mathrm{t}$ tabel yang artinya terdapat perbedaan antara pengetahuan siswa sebelum menggunakan metode membaca Jolly Phonics dan sesudah menggunakan metode Jolly Phonics.

Berdasarkan studi pendahuluan atau analisis kebutuhan awal dinformasi yang diperoleh terkait permasalahan dalam pembelajaran (1) siswa kesulitan mengenali simbol huruf $\mathrm{A}-\mathrm{Z}$, siswa kesulitan membedakan simbol huruf, (2) cermin/mirip, dan (3) siswa kesulitan dalam membaca gabungan kata, suku kata, dan kata. Kemampuan membaca permulaan yang ideal harus dimiliki siswa yaitu siswa dapat membaca teks/tulisan tanpa mengeja. Hasil studi menunjukkan siswa yang memiliki karakteristik membaca melalui mendengarkan bunyi dan mengenal huruf cocok menggunakan metode Jolly Phonics (pendekatan bahasa basic skill and phonics) dan pembelajaran selama ini berlangsung menggunakan metode SAS atau melalui pendekatan whole language. Berdasarkan hasil studi pendahuluan, diperoleh informasi bahwa permasalahan yang muncul yaitu metode yang digunakan kurang sesuai dengan cara belajar siswa kelas I SD yang mengalami kesulitan membaca.

Kunci utama mengatasi kesulitan membaca dengan mengenali cara belajarnya dan memahami konsep pendekatan bahasa secara menyeluruh (whole language approach) dan pendekatan keahlian dasar dan fonik (basic skills and phonics) (Santrock, 2011). Pemilihan pendekatan yang tidak sesuai dengan kemampuan awal membaca dan cara belajar akan memperlambat cara belajar siswa. Oleh karena itu, guru harus mampu mengenali cara belajar siswa. Pendekatan membaca keseluruhan menekankan pada membaca seluruh kata melalui pengulangan, sedangkan pendekatan dasar membaca dan fonik siswa belajar menguraikan kata menjadi bunyi yang membentuknya. Oleh karena itu, cara mengidentifikasi yang tepat dengan cara mencoba melakukan kedua pendekatan ini kepada siswa. Siswa akan memberikan respon terhadap pendekatan yang digunakan. Apabila siswa tetap mengalami kesulitan gunakan pendekatan yang lain dan analisislah bagaimana respon siswa.

Pendekatan bahasa menyeluruh ketika diterapkan kepada anak yang cenderung ke pendekatan keahlian dasar dan fonik akan menimbulkan respon siswa, antara lain (1) siswa tetap mengalami kesulitan mengenali kosakata dan bunyi dari hurufhuruf, (2) siswa tetap mengeja tidak konsisten dan tidak dapat ditebak. Mengeja beberapa kata dengan cara yang bervariasi, (3) harus berusaha keras mempelajari hal-hal yang berurutan, seperti urutan huruf $\mathrm{A}-\mathrm{Z}$ (4) harus berusaha keras mempelajari membedakan huruf-huruf cermin atau mirip, (5) mengucapkan kata yang dibacanya terbalik, seperti edo menjadi deo, (6) tepat menjawab pertanyaan dengan baik secara lisan namun mengalami kesulitan ketika harus memberikan jawaban dalam bentuk tulisan, (7) ketika membaca terdapat satu atau beberapa huruf yang tidak terbaca, dan (8) memori jangka pendek dan masalah dalam pemrosesan visual membuat proses mengingat huruf lebih lama dan siswa lebih ketika pemrosesan visual disertai dengan bunyi yang sifatnya diulang-ulang.

Cara mengidentifikasi pendekatan membaca siswa yaitu dengan melihat dan menganalisis kecenderungan yang tampak dari siswa ketika mereka sedang membaca. Pendekatan dasar dan fonik adalah instruksi phonics yang menekankan korespondensi huruf dan bunyinya sehingga anak yang cenderung cocok dengan pendekatan dasar dan fonik akan menunjukkan cara belajar yang berbeda dengan siswa yang lain yaitu dengan masing-masing huruf dan bunyinya (Widyastuti, 2017). Temuan yang didapatkan pada saat penelitian pengembangan yaitu sebuah langkah-langkah atau prosedur melakukan program remedial membaca permulaan dengan pendekatan basic skill and phonics dan metode Jolly Phonics. Metode Jolly Phonics memiliki tahapan membaca, antara lain (1) learning the letter sound, (2) learning the letter formation, (3) blending, (4) identifying the sound in words (Llyond, 2007).

Pola aktivitas membaca yang diciptakan pada saat pembelajaran dapat dijadikan sebagai alternatif aktivitas/proses dalam membaca. Tahap Pertama, belajar bunyi huruf (learning the letter sound). Aktivitas yang dapat dilakukan, meliputi (1) mengurutkan huruf atau menata huruf $\mathrm{A}-\mathrm{Z}$ yang telah disusun acak, (2) membedakan huruf yang memiliki kemiripan bentuk, (3) mengenalkan gabungan huruf diftong dan bukan diftong atau vokal rangkap dan konsonan rangkap, (4) ulangi kegiatan secara berangsur-angsur, dan (5) lanjutkan ke tahap selanjutnya apabila siswa sudah menguasai tahap I yaitu bunyi huruf. Aktivitas ini didukung oleh pendapat Lestari (2013) bahwa cara tepat mengajarkan anak mengenal bunyi huruf sampai anak benar-benar hafal yaitu dengan cara yang menyenangkan seperti melalui lagu (menyanyi) atau menirukan bunyi huruf yang di ucapkan oleh guru atau pendamping. Menurut (Wahyuni, Fauziati, \& Hikmah, 2016) bahwa tahap pengenalan bunyi merupakan model pembelajaran interaktif dimana siswa meberikan respon dan penerimaan langsung terhadap instruksi.

Tahap kedua, belajar menuliskan bentuk huruf (learning the letter formation). Aktivitas yang dapat dilakukan, yaitu (1) Menulis seluruh huruf $\mathrm{A}-\mathrm{Z}$ dengan melihat contoh penulisan huruf yang tepat, (2) menulis kembali huruf dengan fokus huruf yang memiliki kemiripan bentuk, (3) menulis kembali huruf-huruf yang merupakan kesulitan siswa, (4) menulis huruf secara acak atau menulis huruf sampai membentuk satu kata, (5) mengulangi kegiatan tersebut, dan (6) lanjutkan ke tahap selanjutnya apabila siswa sudah menguasai tahap menulis bentuk huruf. Aktivitas ini didukung dengan oleh pernyataan (Musfiroh, 2009) bahwa langkah membaca dalam mengenalkan huruf yaitu mengenalkan secara bersamaan huruf kecil dan huruf kapital, menampilkan bentuk huruf, dan memberitahukan nama huruf membantu anak dalam membaca. 
Metode Jolly Phonics menurut (Dwiastuti, 2014) bahwa metode Jolly Phonics efektif untuk menstimulus kesiapan membaca siswa terutama dalam pengenalan huruf. Tahap ketiga, memadukan (blending). Aktivitas yang dapat dilakukan, meliputi (1) membaca suku kata, (2) merangkai suku kata menjadi kata yang sesuai, (3) mengulangi aktivitas secara terus menerus, dan (4) lanjutkan ke tahap selanjutnya jika dirasa menguasai tahap memadukan membaca huruf dan suku kata pada sebuah kata. Aktivitas ini didukung oleh pendapat (Atikah, 2014) bahwa membaca menggunakan suku kata merupakan cara membaca integratif karena terjadi proses pengenalan huruf dengan pola suku kata dan merupakan cara efektif untuk melatih siswa dalam membaca.

Tahap keempat, mengidentifikasi bunyi kata (identifying the sound in words). Aktivitas yang dapat dilakukan, meliputi (1) menyuarakan sebuah kata dengan lantang dengan lafal dan intonasi yang tepat, (2) menentukan tulisan dari bunyi kata yang telah diucapkan, (3) ulangi kegiatan dari awal dan terus berulang, dan (4) kegiatan menentukan huruf dapat melalui menulis, memilih kartu kata sesuai kreativitas guru. Aktivitas ini didukung oleh pendapat (Mather \& Wendling, 2011) bahwa fonik merupakan cara membaca yang dapat melatih siswa mengidentifikasi suara terhadap tulisan sehingga membuat tulisan mudah di ucapkan oleh siswa. Menurut (Callinan \& Zee, 2010) pengenalan kata yang mengacu pada pengucapan kata-kata ini akan melatih siswa cepat membaca tanpa menganalisis struktur kata. Penelitian lain menunjukkan bahwa Jolly Phonics dapat membuat peningkatan yang lebih besar dalam tugas membaca kata-kata dan fonem pada siswa kelas pertama.

Tahapan membaca Jolly Phonics akan mengatasi kesulitan membaca anak. Hal ini didukung dan dibuktikan oleh penelitian terdahulu yang dilakukan (Ramadhan \& Dhoerman, 2014) diperoleh informasi bahwa perbandingan kemampuan membaca dengan sebelum menggunakan Jolly Phonics dan sesudah menggunakannya melaui uji Asymp Sig (Tailed) yaitu 0,005 yang lebih kecil dari 5\% diperoleh hipotesis nol ditolak yang artinya terdapat pengaruh penggunaan metode membaca Jolly Phonics terhadap kemampuan membaca siswa kelas I SD. Pendapat yang sama dinyatakan oleh (Farokhbakht \& Nejadansari, 2015) bahwa hasil menunjukkan bahwa kelompok eksperimen (Jolly Phonics) memiliki kinerja yang lebih baik pada tes membaca dan mengeja.

Aktivitas yang sesuai dengan metode membaca Jolly Phonics dapat mengatasi kesulitan siswa. Hal ini telah dibuktikan oleh (Thaen-nga \& Leenam, 2016) mengungkapkan efek utama yang signifikan secara statistik (P <.001) menunjukkan bahwa ada perbedaan yang signifikan antara nilai rata-rata dari pretest dan posttest yang berarti bahwa siswa meningkatkan kemampuan membaca mereka setelah diajarkan melalui Jolly Phonics. Melalui tahapan-tahapan tersebut telah dibuktikan oleh (Ifeoma \& Ibiam, 2013) bahwa pada tingkat signifikansi 0,05 menunjukkan tahan blending atau pencampuran bunyi huruf dan identifikasi bunyi huruf pada kata-kata memiliki efek yang signifikan pada kemampuan membaca siswa.

\section{SIMPULAN}

Metode Jolly Phonics adalah metode membaca permulaan yang menekankan mutisensori dan pengenalan simbol tulisan melalui unsur terkecil, yaitu huruf beserta bunyinya. Metode membaca ini cocok digunakan untuk siswa yang memiliki dan cenderung belajar melalui pendekatan bahasa basic skill and phonics. Metode Jolly Phonics dilakukan melalui tahapan membaca, yaitu (1) learning the letter sound, (2) learning the letter formation, (3) blending, (4) identifying the sound in words. Metode Jolly Phonics efektif membantu dan mengatasi kesulitan siswa dalam membaca permulaan. Hal ini didukung oleh hasil perhitungan peneliti terhadap pengetahuan (hasil belajar siswa) dan performa (kemampuan membaca siswa). Hasil perhitungan performa t hitung yaitu 2,422 dan t tabel yaitu 1,812 artinya terdapat perbedaan. Hasil perhitungan pengetahuan menunjukkan hasil perolehan t hitung yaitu 2,663 dan $t$ tabel yaitu 1,812, artinya terdapat perbedaan.

Melatih membaca terutama membaca permulaan di kelas awal harus memperhatikan gaya belajar siswa. Gaya belajar akan menentukan pendekatan bahasa yang sesuai dengan cara belajar siswa. Hal ini akan membantu dalam menentukan metode membaca yang tepat sasaran pada kesulitan yang dihadapi oleh siswa. Penanganan kesulitan membaca permulaan harus teratasi dan dilakukan secara intensif agar siswa memiliki kemampuan membaca yang sesuai dengan kondisi ideal siswa kelas I SD.

\section{DAFTAR RUJUKAN}

Ariati, N. P. P., Padmadewi, N. N., \& Suarnajaya, I. W. (2018). Jolly Phonics : Effective Strategy Enhancing Children English Literacy. SHS Web of Conferences, 42(00032), 1-7. https://doi.org/https://doi.org/10.1051/shsconf/20184200032

Atikah, S. (2014). Metode 5 Langkah Pintar Membaca. Jakarta: Wahyumedia.

Callinan, C., \& Zee, E. VanDer. (2010). A Comparative Study of Two Methods of Synthetic Phonics Instruction for Learning How To Read: Jolly Phonics and THRASS. The Psychology of Education, 34(1), 21-31.

Dewi, S. U. S. (2015). Pengaruh Metode Multisensori Dalam Meningkatkan Kemampuan Membaca Permulaan pada Anak Kelas Awal Sekolah Dasar. Jurnal Program Studi PGMI, 2(1), 1-13. Retrieved from http://jurnal.stitnualhikmah.ac.id/index.php/modeling/article/view/43/43

Dwiastuti, I. (2014). Metode Jolly Phonics sebagai Alternatif Stimulasi Kesiapan Membaca Anak Usia Dini. Jurnal Sains Psikologi, 3(1). 
Farokhbakht, L., \& Nejadansari, D. (2015). The Effect of Using Synthetic Multisensory Phonics In Teaching Literacy on EFL Young Learners ’ Literacy Learning. International Journal of Research Studies in Education, 4(4), 39-52. https://doi.org/10.5861/ijrse.2015.1196

Faustina, E. (2008). The Effectiveness of Jolly Phonics in Teaching a 4 Year Old Indonesian Child to Read English Text. Journal Universitas Airlangga, 3(2), 74-80. https://doi.org/10.1016/j.clinph.2011.04.028

Ifeoma, O. M., \& Ibiam, J. U. (2013). The Efficacy of Jolly Phonics Instructional Strategy on The Writing Ability of Junior Primary Pupils' In Uyo Senatorial District of Akwa Ibom State, Nigeria. Merit Research Journal of Education and Review, 1(9), 203-207.

Llyond. (2007). Jolly Phonics Handbook. A Handbook Of Teaching Reading, Writing, and Spelling. London: Jolly Learning Ltd.

Mather, N., \& Wendling, B. J. (2011). Essentials of Dyslexia Assessment and Intervention. United States: John Wiley \& Sons.

Musfiroh, T. (2009). Menumbuhkembangkan Baca-Tulis Anak Usia Dini. Jakarta: Grasindo.

Nasrawi, A., \& Al-Jamal, D. (2017). The Effect of Using Jolly Phonics on Jordanian First Grade Pupils' Reading. International Online Journal of Education and Teaching, 4(2), 106-119. Retrieved from http://iojet.org/index.php/IOJET/article/view/172/155

Ramadhan, S. A. A., \& Dhoerman, T. D. (2014). Pengaruh Pemberian Metode Jolly Phonics Terhadap Kemampuan Membaca Permulaan yang Kesulitan Membaca pada Siswa Kelas 1 di SD Yayasan Padjajaran. Prosiding Psikologi, 3(1), 113117.

Ruhaena, L. (2008). The Effect of Jolly Phonics Learning Method on The Indonesian and English Initial Literacy Ability In Preschool Children. Jurnal Penelitian Humaniora, 9(2), 192-206.

Santrock, J. W. (2011). Perkembangan Anak Edisi 7. Jakarta: Erlangga.

Sudiarta, I. W. (2017). Pengaruh Metode Jolly Phonics Terhadap Kemampuan Membaca Dan Menulis Permulaan Bahasa Inggris pada Anak Kelompok B TK Mahardika Denpasar. Jurnal Ilmiah Pendidikan dan Pembelajaran, 1(3), 240-251.

Thaen-nga, J., \& Leenam, W. (2016). The Use of Phonics Instruction To Enhance Students ' Reading Ability : A Case Study of Grade 3 Students At Nam Yuen School, Nam Yuen District, Ubon Ratchathani. International Journal of Research, 4(10), 65-71. https://doi.org/10.5281/zenodo.164923

Wahyuni, N. T., Fauziati, E., \& Hikmah, M. (2016). The Effectiveness of Using Phonics Instruction And Storybooks In English Reading Classes To Improve Student Participation. Jurnal Penelitian Humaniora, 18(1), 49-64. https://doi.org/10.1111/j.1365-2486.2005.01075.x

Widyastuti, A. (2017). Kiat Jitu Anak Gemar Baca Tulis. Jakarta: PT Elex Media Komputindo. 